\title{
Pengaruh propolis terhadap profil lipid plasma tikus model hiperkolesterolemia
}

\author{
The effect of propolis on lipid profile of hypercholesterolemic rat model
}

Diah Krisnansari', Ariadne Tiara Hapsari', Evy Sulistyoningrum ${ }^{1}$, Agus Prastowo²

\begin{abstract}
Background: Nowadays, cardiovascular disease caused by hypercholesterolemia has become the main cause of death. Propolis has been used widely to reduce plasma cholesterol levels.

Objective: The aims of this research was to study the effect of propolis on lipid profile of hypercholesterolemic Sprague Dawley rats.

Method: This was an experimental study with pre-post test. Twenty four (24) male Sprague Dawley rats aged 12-16 weeks, weighing 125-200 g were allocated into 4 groups. Group I received standard meal + aquadest-gavage; group II received high cholesterol meal + PTU 0,01 + aquadest gavage; group III received high cholesterol meal + PTU 0,01 + 0,027 g propolis gavage; group IV received high cholesterol meal + PTU 0,01 + 0,054 g propolis gavage. Total cholesterol, triglyceride, HDL cholesterol and LDL cholesterol levels before and after treatment were measured. The data were then analyzed with One Way Anova.

Results: The study showed that there were no significant differences in changes of body weight. There were significant differences in total cholesterol levels between all groups of treatment. Triglyceride levels were significantly different among all groups, except between group I and IV. Furthermore, the HDL cholesterol levels of group I vs III and group I vs IV were significantly different. However, there were no differences found in LDL cholesterol levels among all groups of treatment.

Conclusion: Provision of 0,027 $\mathrm{g}$ and $0,054 \mathrm{~g}$ propolis improve lipid profile (total cholesterol, triglyceride and HDL cholesterol levels) of hypercholesterolemic rats.
\end{abstract}

KEY WORDS total cholesterol, triglyceride, HDL cholesterol, LDL cholesterol, propolis

\begin{abstract}
ABSTRAK
Latar belakang: Saat ini penyakit kardiovaskular yang disebabkan oleh hiperkolesterolemia telah menjadi penyebab utama kematian. Propolis telah banyak digunakan masyarakat luas untuk menurunkan kolesterol darah.

Tujuan: Mengetahui pengaruh propolis terhadap perubahan profil lipid tikus putih strain Sprague Dawley model hiperkolesterolemia.

Metode: Penelitian ini merupakan studi eksperimental dengan desain pre-post test. Dua puluh empat (24) ekor tikus putih (Rattus norvegicus) jantan strain Sprague Dawley berumur 12-16 minggu dengan berat badan 125-200 g dikelompokkan menjadi 4 kelompok. Kelompok I mendapatkan pakan standar + sonde aquades; kelompok II mendapatkan pakan tinggi kolesterol + PTU 0,01\% + sonde aquades; kelompok III mendapatkan pakan tinggi kolesterol + PTU 0,01\% + sonde propolis 0,027 g; kelompok IV mendapatkan pakan tinggi kolesterol + PTU 0,01\% + sonde propolis 0,054 g. Sebelum dan sesudah perlakuan dilakukan pengukuran terhadap kadar kolesterol total, trigliserida, kolesterol HDL, dan kolesterol LDL. Data kemudian dianalisis menggunakan One Way Anova.

Hasil: Hasil penelitian menunjukkan bahwa tidak ada perbedaan yang signifikan dalam perubahan berat badan. Ada perbedaan yang signifikan pada kadar kolesterol total antara semua kelompok perlakuan. Kadar trigliserida secara signifikan berbeda di antara semua kelompok kecuali antara kelompok I dan IV. Selain itu, kadar kolesterol HDL kelompok I vs III dan kelompok I vs IV secara signifikan berbeda. Namun tidak ada perbedaan kadar kolesterol LDL yang signifikan pada semua kelompok perlakuan.

Kesimpulan: Propolis dosis 0,027 g dan 0,054 g dapat memperbaiki profil lipid (kadar kolesterol total, trigliserida, dan kolesterol HDL) tikus hiperkolesterolemia.
\end{abstract}

KATA KUNCI: kolesterol total, trigliserida, kolesterol HDL, kolesterol LDL, propolis

\section{PENDAHULUAN}

Penyebab utama kematian manusia saat ini adalah penyakit jantung dan pembuluh darah (PJPD). Di seluruh dunia, penyakit jantung menyebabkan 1 dari setiap 4 kematian. Kejadian ini tidak berbeda antara wanita dan pria, walaupun wanita rata-rata meninggal akibat penyakit

\footnotetext{
1 Jurusan Kedokteran Fakultas Kedokteran dan IImu-IImu Kesehatan, Universitas Jenderal Soedirman, Kampus FKIK Unsoed Berkoh, JI. Dr. Gumbreg/Jl. Medika, Purwokerto, Jawa Tengah, Telp/Fax (0281) 622022, e-mail: krisnansari@gmail.com

${ }^{2}$ Instalasi Gizi Rumah Sakit Prof. Dr. Margono Soekarjo, JI. Dr. Gumbreg No. 1 Purwokerto, Jawa Tengah, e-mail: pras_cakeb@yahoo.co.id
} 
jantung 10 tahun lebih tua daripada pria. Di Amerika Serikat maupun di beberapa negara berkembang, PJPD merupakan penyebab kematian utama. Dari sejumlah kematian akibat PJPD, 53\%-nya disebabkan oleh penyakit jantung iskemia (PJI) (1). Data nasional berdasarkan riset kesehatan dasar (Riskesdas) tahun 2007, prevalensi penyakit jantung sebesar $7,2 \%$ berdasarkan hasil wawancara dan $0,9 \%$ berdasarkan riwayat diagnosis tenaga kesehatan. Cakupan yang sudah didiagnosis oleh tenaga kesehatan yaitu $12,5 \%$ mempunyai gejala subjektif menyerupai gejala penyakit jantung (2).

Kecurigaan adanya hubungan asupan lemak dengan penyakit jantung sudah muncul kurang lebih 200 tahun yang lalu. Pada abad ke-18, para dokter umum mencatat bahwa orang yang meninggal karena serangan jantung memiliki tanda-tanda penumpukan lemak pada dinding pembuluh darah arteri jantung. Penyebab terbanyak PJPD adalah aterosklerosis yang erat kaitannya dengan hiperkolesterolemia (1). Hiperkolesterolemia adalah keadaan yang terjadi akibat kelebihan kadar kolesterol darah (3). Empat puluh persen kematian mendadak akibat PJPD disebabkan oleh hiperkolesterolemia (4).

Di Indonesia prevalensi hiperkolesterolemia semakin meningkat. Menurut hasil penelitian Monica Core Study (MONICA) di Jakarta pada tahun 1988 menunjukkan bahwa rata-rata kadar kolesterol total pada wanita sebesar 206,6 mg/dl dan pria 199,8 mg/dl, tahun 1993 meningkat menjadi 213,0 mg/dl pada wanita dan 204,8 mg/dl pada pria. Beberapa daerah dengan nilai kolesterol yang sama yaitu Surabaya (tahun 1985) sebesar $195 \mathrm{mg} / \mathrm{dl}$, Ujung Pandang (tahun 1990) sebesar 219 mg/dl, dan Malang (tahun 1994) sebesar $206 \mathrm{mg} / \mathrm{dl}$ (5).

Hiperkolesterolemia dipercepat oleh reaksi stres oksidatif. Reaksi stres oksidatif menyebabkan kerusakan makromolekul biologis dan gangguan sistem aliran tubuh meliputi oksidasi low density lipoprotein (LDL), disfungsi endotelial, dan peningkatan respon inflamasi. Radikal bebas akan menyebabkan lipid pada membran sel mengalami reaksi peroksidasi (oksidasi) (6). Berbagai usaha untuk mengatasi hiperkolesterolemia telah banyak dikembangkan di antaranya memperbaiki pola hidup dengan diit rendah lemak, menghindari faktor risiko merokok serta pemberian obat-obatan (7). Obat-obatan bekerja dengan mengonversi kolesterol yang dihasilkan hati menjadi asam empedu atau dengan menghambat sistem enzim hati dalam pembentukan kolesterol (3). Dewasa ini diketahui bahwa obat kimia modern mempunyai banyak dampak negatif baik secara langsung maupun tidak langsung (8). Di samping itu, meningkatnya harga obat menyebabkan daya beli masyarakat menurun (9).

Propolis merupakan obat herbal yang banyak dikonsumsi masyarakat dan dipercaya dapat menurunkan kolesterol darah, namun belum banyak penelitian yang mengkaji hal tersebut. Propolis adalah getah yang dikumpulkan oleh lebah dari berbagai jenis pucuk tanaman dan dari tanaman yang patah. Getah tanaman tersebut kemudian dicampur dengan enzim yang terdapat dalam kelenjar ludah lebah dan digunakan untuk melindungi sarang dari berbagai bakteri, virus, dan jamur. Propolis telah digunakan dalam pengobatan populer sejak 300 tahun yang lalu di berbagai belahan dunia, meskipun aktivitas farmakologi komposisi kimia propolis baru diketahui sekitar 40 tahun yang lalu $(10,11,12)$.

Propolis mengandung berbagai zat di antaranya terpen dan benzoat yang potensial, caffeate, sinamat, asam phenolat, dan flavonoid, beberapa mineral seperti magnesium (Mg), kalsium (Ca), iodium (I), kalium (K), natrium $(\mathrm{Na})$, tembaga $(\mathrm{Cu})$, zink $(\mathrm{Zn})$, dan besi $(\mathrm{Fe})$, beberapa vitamin seperti vitamin B1, B2, B6, C, dan E serta beberapa asam lemak $(13,14,15,16,17)$. Dari berbagai zat yang terkandung dalam propolis, disebutkan bahwa flavonoid dan vitamin antioksidan merupakan zat yang dapat melindungi membran lipid dari proses peroksidasi (10). Oleh karena itu perlu dilakukan penelitian pengaruh propolis terhadap profil lipid. Penelitian dilakukan dengan menggunakan hewan coba dan bertujuan untuk mengetahui pengaruh propolis terhadap kadar profil lipid plasma tikus putih model hiperkolesterolemia yang diinduksi eksogen dan endogen.

\section{BAHAN DAN METODE}

Penelitian dilaksanakan selama 4 minggu yaitu pada tanggal 20 September 2010 sampai dengan 22 Oktober 2010. Penelitian dilakukan di Laboratorium Farmakologi Jurusan Kedokteran, Fakultas Kedokteran dan IImu-ilmu Kesehatan (FKIK) untuk pemeliharaan dan perlakuan hewan coba dan Laboratorium Biokimia Jurusan Kedokteran FKIK untuk pemeriksaan laboratorium kolesterol total, trigliserida, kolesterol LDL, dan high density lipoprotein (HDL).

Penelitian ini merupakan penelitian eksperimental dengan rancangan pre-post test control study. Dosis propolis dalam penelitian ini adalah dosis manusia dikalikan faktor konversi (manusia dengan berat badan $70 \mathrm{~kg}$ dikonversi pada tikus dengan berat $200 \mathrm{~g}$ ). Dosis propolis yang digunakan pada pengobatan kolesterol manusia berkisar $1,5 \mathrm{~g}$ per hari (10).

Penelitian menggunakan hewan coba 24 ekor tikus putih (Rattus norvegicus) jantan strain Sprague Dawley berumur 12-16 minggu, sehat, dan berat badannya berkisar 125-200 g. Semua hewan coba ditempatkan dalam kandang yang terbuat dari bahan yang sama yaitu dari keranjang plastik diberi alas jerami, dipelihara dalam lingkungan dengan suhu dan kelembapan yang sama, mendapat pencahayaan alami, dan minuman hewan coba juga sama. Perlakuan hewan coba dilakukan selama 20 hari. Tikus dikelompokkan menjadi empat kelompok yang dapat dilihat pada Gambar 1. Pada hari ke-28 


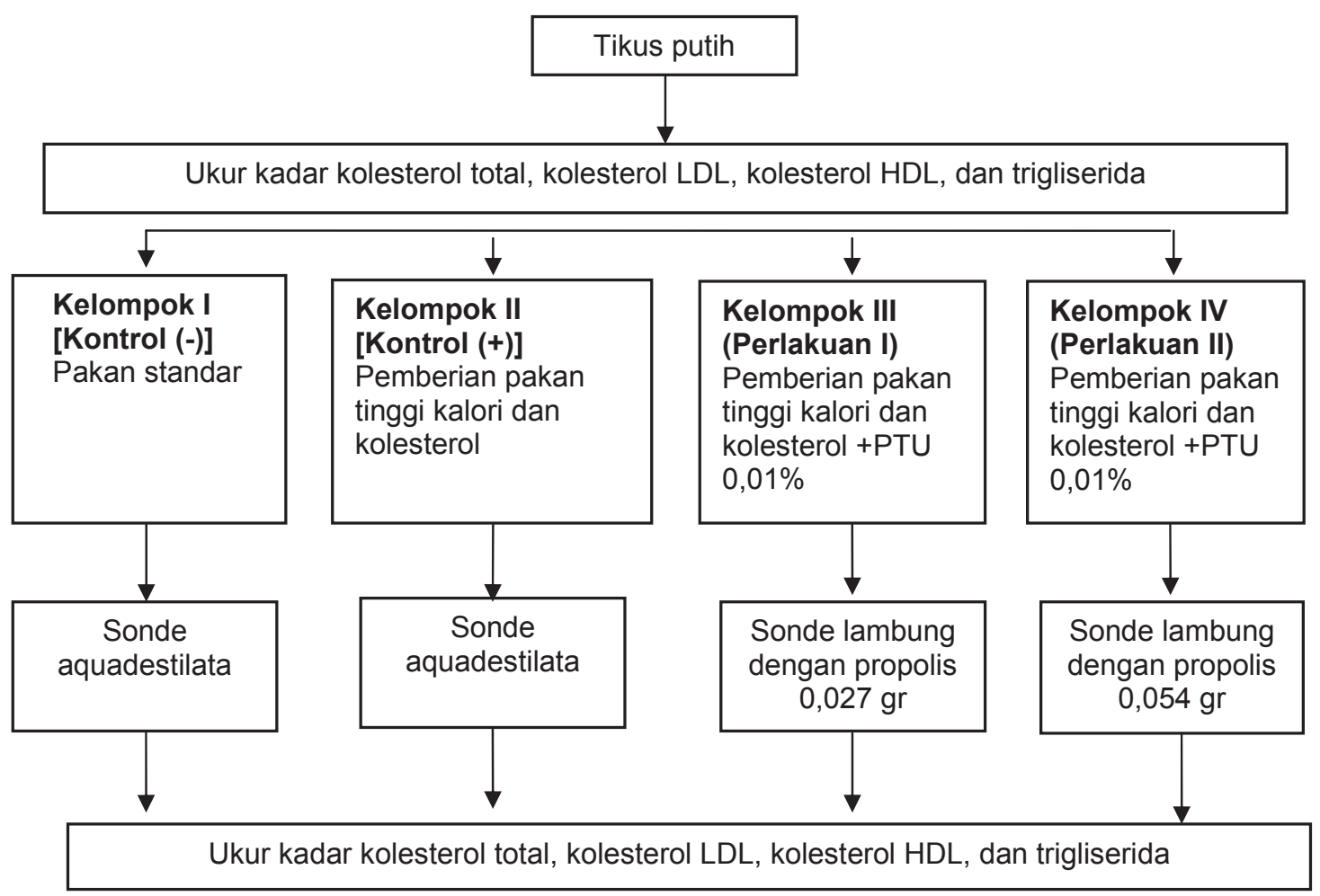

Gambar 1. Skema alur penelitian

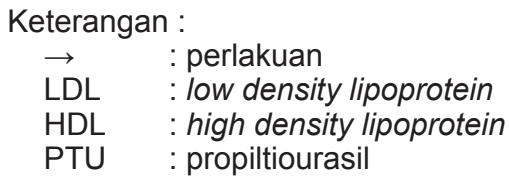

hewan dipuasakan selama 12 jam, kemudian dilakukan pengambilan darah melalui sinus orbitalis yang selanjutnya diperiksa seperti pemeriksaan sebelum perlakuan (18). Propolis dengan dosis di atas diencerkan dalam aquades sehingga tercapai volume $10 \mathrm{ml}$ sesuai dengan volume maksimal obat yang diberikan pada tikus dengan berat 200 g secara oral (18). Bahan-bahan perlakuan aquadestilata dan propolis dipersiapkan dalam bentuk larutan yang siap dipergunakan untuk percobaan dan disimpan dalam pendingin bersuhu $\pm 4^{\circ} \mathrm{C}$. Propiltiourasil (PTU) $0,01 \%$, bahan pakan standar, dan bahan pakan tinggi kolesterol disimpan dalam almari dengan suhu dan kelembapan yang sama. Pakan tinggi kolesterol dengan komposisi $1,5 \%$ kuning telur (19), $6 \%$ lemak kambing, $6 \%$ minyak goreng curah, dan pakan standar sampai $100 \%$ (20).

Hewan coba pada awalnya diadaptasikan selama 7 hari sebelum penelitian dan selama penelitian diberi asupan makanan dan air yang cukup. Pada hari ke-7 hewan dipuasakan selama 12 jam, kemudian dilakukan pengambilan darah melalui sinus orbitalis. Canthus medialis mata ditusuk dengan menggunakan tabung mikrohematokrit sampai mengenai vena retro-orbitalis (18). Sampel darah yang keluar ditampung dalam tabung reaksi sebanyak $\pm 2 \mathrm{ml}$. Darah disentrifus dengan kecepatan $3.000 \mathrm{rpm}$ (rounds per minute) selama 10 menit. Plasma yang dihasilkan digunakan sebagai sampel untuk pemeriksaan kadar kolesterol total, trigliserida, kolesterol HDL, dan kolesterol LDL. Analisis perbedaan rerata tiap variabel antar kelompok dilakukan dengan uji analysis of variance (One Way Anova) dengan signifikansi p kurang dari 0,05 dan taraf kepercayaan 95\% $(\alpha=0,05)(21)$.

\section{HASIL}

Karakteristik kondisi awal semua tikus dalam kondisi homogen, kadar kolesterol total, trigliserida, kolesterol HDL, dan kolesterol LDL normal. Pada akhir perlakuan rerata berat badan semua tikus meningkat dengan rerata kenaikan berat badan paling banyak pada kelompok I $(63,3 \mathrm{~g})$ dan rerata kenaikan berat badan paling sedikit pada kelompok III (40 g) (Tabel 1).

Rerata kolesterol total hewan coba kelompok I, II, dan III meningkat pada akhir perlakuan dengan rerata peningkatan kolesterol total paling banyak pada kelompok II $(27,1 \mathrm{mg} /$ dl) dan rerata peningkatan kolesterol total paling sedikit pada kelompok I (2,9 mg/dl) sedangkan rerata kolesterol total kelompok IV menurun pada akhir perlakuan. Rerata trigliserida hewan coba kelompok I, II, dan III meningkat pada akhir perlakuan dengan rerata peningkatan trigliserida paling banyak pada kelompok II (110,5 mg/dl) dan rerata peningkatan trigliserida paling sedikit pada kelompok I (3,8 $\mathrm{mg} / \mathrm{dl}$ ) sedangkan rerata trigliserida kelompok IV menurun 
Tabel 1. Karakteristik rerata perubahan berat badan dan profil lipid hewan coba sebelum dan setelah perlakuan

\begin{tabular}{|c|c|c|c|c|c|}
\hline Variabel & Kelompok & Rerata sebelum & Rerata sesudah & Delta & $\mathbf{p}$ \\
\hline \multirow[t]{4}{*}{ Berat badan (g) } & 1 & 154,2 & 217,5 & 63,3 & \\
\hline & II & 166,7 & 213,3 & 46,70 & \\
\hline & III & 166,7 & 206,7 & 40,0 & $0,572^{b}$ \\
\hline & IV & 139,2 & 192,5 & 53,3 & \\
\hline \multirow[t]{4}{*}{ Kolesterol total (mg/dl) } & I & 70,8 & 73,7 & 2,9 & \\
\hline & II & 89,2 & 116,3 & 27,1 & $0,000^{a}$ \\
\hline & III & 68,3 & 75,5 & 7,2 & $0,011^{b}$ \\
\hline & IV & 81,8 & 74,8 & $-7,0$ & \\
\hline \multirow[t]{4}{*}{ Trigliserida (mg/dl) } & 1 & 63,2 & 67 & 3,8 & \\
\hline & II & 75,5 & 186 & 110,5 & $0,000^{a}$ \\
\hline & III & 67 & 96,5 & 29,5 & $0,039^{b}$ \\
\hline & IV & 107,5 & 89,3 & $-18,2$ & \\
\hline \multirow[t]{4}{*}{ Kolesterol HDL (mg/dl) } & 1 & 32,7 & 34,5 & 1,8 & \\
\hline & II & 41 & 34,5 & $-6,5$ & $0,014^{c}$ \\
\hline & III & 42,7 & 46,2 & 3,5 & $0,030^{\mathrm{a}}$ \\
\hline & IV & 43,8 & 49,3 & 5,5 & \\
\hline \multirow[t]{4}{*}{ Kolesterol LDL (mg/dl) } & I & 25,5 & 25,8 & 0,3 & \\
\hline & II & 33,1 & 44,6 & 11,5 & $0,147^{a}$ \\
\hline & III & 12,2 & 10,1 & $-2,1$ & $0,478^{b}$ \\
\hline & IV & 19,8 & 7,6 & $-12,2$ & \\
\hline
\end{tabular}

Keterangan: ${ }^{a}=$ Uji Homogenity

$\mathrm{b}=$ Uji One Way Anova

$c=$ Uji Kruskal Wallis

$\mathrm{HDL}=$ high density lipoprotein

$\mathrm{LDL}=$ low density lipoprotein

pada akhir perlakuan. Rerata kolesterol HDL hewan coba pada kelompok I, III, dan IV meningkat pada akhir perlakuan dengan rerata peningkatan kolesterol HDL paling banyak pada kelompok IV $(5,5 \mathrm{mg} / \mathrm{dl})$ dan rerata peningkatan kolesterol HDL paling sedikit pada kelompok I $(1,8 \mathrm{mg} / \mathrm{dl})$ sedangkan rerata kolesterol HDL hewan coba kelompok II menurun pada akhir perlakuan $(6,5 \mathrm{mg} / \mathrm{dl})$. Rerata kolesterol LDL hewan coba yang mengalami peningkatan pada akhir perlakuan terdapat pada kelompok I ( $0,3 \mathrm{mg} / \mathrm{dl})$ dan kelompok Il (11,5 mg/dl) sedangkan rerata kolesterol LDL hewan coba yang mengalami penurunan pada akhir perlakuan terdapat pada kelompok III (2,1 mg/dl) dan kelompok IV (12,2 mg/dl) (Tabel 1).

Uji statistik diawali dengan melakukan uji normalitas data perubahan berat badan, perubahan kolesterol total, perubahan trigliserida, perubahan kolesterol HDL, dan perubahan kolesterol LDL. Uji Shapiro-Wilk $(p>0,05)$ untuk perubahan berat badan, kolesterol total, dan trigliserida menunjukkan data terdistribusi normal dan dianalisis menggunakan One Way Anova. Perubahan kolesterol HDL dan kolesterol LDL dengan uji Saphiro-Wilk $(p<0,05)$ diperoleh data terdistribusi tidak normal dan dilakukan transformasi data. Penentuan bentuk transformasi yaitu dengan mencari slope dan power data terlebih dahulu. Diperoleh slope perubahan kolesterol HDL sebesar 0,698 dan power perubahan kolesterol HDL sebesar 0,302 sehingga bentuk transformasi dengan square root.
Diperoleh slope perubahan kolesterol LDL sebesar 0,506 dan power perubahan kolesterol LDL sebesar 0,494 sehingga bentuk transformasi dengan square root. Hasil uji normalitas transformasi data perubahan kolesterol HDL didapatkan nilai $p$ kurang dari 0,05 sehingga data terdistribusi tidak normal dan analisis data menggunakan Kruskal Wallis. Hasil uji normalitas transformasi data perubahan kolesterol LDL didapatkan nilai $p$ lebih dari 0,05 sehingga data terdistribusi normal dan dianalisis menggunakan One Way Anova.

Berdasarkan Tabel 1 didapatkan hasil uji One Way Anova untuk data perubahan berat badan dan perubahan kolesterol LDL didapatkan nilai $p$ lebih dari $0,05(p=0,572$ dan $p=0,478$ ), yang artinya tidak terdapat perbedaan perubahan berat badan dan perubahan kolesterol LDL yang bermakna pada semua kelompok perlakuan. Perubahan trigliserida didapatkan nilai $p$ kurang dari $0,05(p=0,000)$, artinya terdapat perbedaan perubahan trigliserida yang bermakna pada semua kelompok perlakuan. Hasil Uji One Way Anova perubahan kolesterol total setelah transformasi didapatkan nilai $p$ kurang dari $0,05(p=0,000)$, artinya terdapat perbedaan perubahan kolesterol total yang bermakna pada semua kelompok perlakuan. Analisis perubahan kolesterol HDL dengan Kruskal Wallis diperoleh nilai $p$ kurang dari $0,05(p=0,014)$, artinya terdapat perbedaan kolesterol HDL pada semua kelompok perlakuan. 
Tabel 2. Uji Post Hoc

\begin{tabular}{ccccc}
\hline No & Variabel & \multicolumn{2}{c}{ Kelompok } & p \\
\hline 1 & Delta kolesterol total & I & II & $0,000^{\mathrm{a}}$ \\
& & & III & $0,001^{\mathrm{a}}$ \\
& & II & IV & $0,006^{\mathrm{a}}$ \\
& & & III & $0,037^{\mathrm{a}}$ \\
& & III & IV & $0,078^{\mathrm{a}}$ \\
\hline 2 & Delta trigliserida & I & II & $0,002^{\mathrm{a}}$ \\
\hline & & & III & $0,037^{\mathrm{a}}$ \\
& & & IV & $0,070^{\mathrm{a}}$ \\
& & II & III & $0,000^{\mathrm{a}}$ \\
& & & IV & $0,000^{\mathrm{a}}$ \\
& & III & IV & $0,000^{\mathrm{a}}$ \\
\hline 3 & Delta kolesterol HDL & I & II & - \\
& & & III & $0,024^{\mathrm{b}}$ \\
& & & IV & $0,014^{\mathrm{b}}$ \\
& & II & III & - \\
& & & IV & - \\
& & III & IV & $0,248^{\mathrm{b}}$
\end{tabular}

Keterangan : ${ }^{a}=$ Fisher's Least Significant Difference (LSD) ${ }^{\mathrm{b}}=$ Mann Whitney

Uji Post Hoc dilakukan dengan uji LSD untuk perubahan kolesterol total dan trigliserida, sedangkan uji Post Hoc Mann Whitney $U$ untuk perubahan kolesterol HDL yang hasilnya dapat dilihat pada Tabel 2.

Hasil uji analisis Post Hoc menunjukkan adanya perbedaan perubahan kolesterol total berbeda secara bermakna antara kelompok I dan II, antara kelompok I dan III, antara kelompok I dan IV, antara kelompok II dan III. Perbedaan perubahan kolesterol total tidak berbeda secara bermakna antara kelompok II dan IV, antara kelompok III dan IV. Perbedaan perubahan trigliserida berbeda secara bermakna pada semua kelompok kecuali antara kelompok I dan IV tidak berbeda secara bermakna. Perbedaan perubahan kolesterol HDL berbeda secara bermakna antara kelompok I dan III, antara kelompok I dan IV. Perbedaan perubahan kolesterol HDL tidak berbeda secara bermakna antara kelompok III dan IV.

\section{BAHASAN}

Berat badan semua hewan coba meningkat setelah perlakuan disebabkan oleh pemberian pakan dan minuman secukupnya secara teratur setiap hari kepada semua hewan coba. Rerata kolesterol total hewan coba pada kelompok II mengalami peningkatan tertinggi yaitu $27,1 \mathrm{mg} / \mathrm{dl}$ karena kelompok II mendapat perlakuan pakan tinggi kolesterol saja, sedangkan rerata kenaikan kolesterol total paling rendah pada kelompok I $(2,9 \mathrm{mg} / \mathrm{dl})$ karena hanya mendapat pakan standar. Rerata kolesterol total hewan coba kelompok III mengalami peningkatan pada akhir perlakuan yaitu $7,2 \mathrm{mg} / \mathrm{dl}$ tetapi peningkatan ini tidak sebanyak kelompok II karena selain mendapat pakan tinggi kolesterol juga mendapat propolis $0,17 \mathrm{~g}$. Sedangkan rerata kolesterol total hewan coba pada kelompok IV menurun pada akhir perlakuan sebanyak $7 \mathrm{mg} / \mathrm{dl}$ karena selain mendapat pakan tinggi kolesterol juga mendapat propolis $0,54 \mathrm{~g}$.

Hal tersebut sesuai dengan penelitian di Surakarta pada tahun 2007 (20) yang menyatakan bahwa pemberian pakan kolesterol meningkatkan kolesterol darah tikus putih Sprague Dawley. Peningkatan kadar kolesterol darah tersebut disebabkan oleh pemberian pakan tinggi kolesterol disertai dengan pemberian PTU. Hasil penelitian ini juga sesuai dengan penelitian di Korea yang mendapatkan pemberian propolis $75 \mathrm{mg} / \mathrm{kg}$ dapat menurunkan kolesterol total tikus dengan diit tinggi kolesterol $1 \%$ dan sodium cholate $0,25 \%$ (12).

Kelompok Kerja Ilmiah Phyto Medica (22) menyebutkan bahwa pemberian kolesterol dan PTU merupakan usaha untuk menginduksi tikus sehingga tercapai kondisi hiperlipidemia. Penambahan 2\% kolesterol pada pakan standar selama 3 hari mampu menimbulkan hiperkolesterolemia pada tikus percobaan (23). PTU merupakan zat antitiroid yang mampu menghambat pembentukan hormon tiroid yang berperan pada lipolisis sehingga penghambatan tiroid ini meningkatkan konsentrasi kolesterol darah melalui peningkatan biosintesis kolesterol endogen $(24,25)$. Selain itu penggunaan lemak kambing dan minyak goreng curah juga memicu peningkatan kadar kolesterol darah karena mengandung asam lemak jenuh.

Rerata trigliserida pada hewan coba kelompok II mengalami peningkatan yang paling tinggi yaitu $110,5 \mathrm{mg} /$ dl karena kelompok II mendapat perlakuan pakan tinggi kolesterol saja, sedangkan rerata peningkatan trigliserida paling rendah pada kelompok I (3,8 mg/dl) karena hanya mendapat pakan standar. Rerata trigliserida pada hewan coba kelompok III mengalami peningkatan pada akhir perlakuan yaitu $29,5 \mathrm{mg} / \mathrm{dl}$ tetapi peningkatan ini tidak sebanyak kelompok II karena selain mendapat pakan tinggi kolesterol juga mendapat propolis $0,17 \mathrm{~g}$. Sedangkan kadar trigliserida kelompok IV menurun pada akhir perlakuan sebanyak $18,2 \mathrm{mg} / \mathrm{dl}$ karena selain mendapat pakan tinggi kolesterol juga mendapat propolis $0,54 \mathrm{~g}$. Peningkatan kadar trigliserida ini terjadi karena kerusakan metabolisme trigliserida (20). Propolis dengan dosis $0,027 \mathrm{~g}$ dapat mencegah kenaikan trigliserida dan propolis $0,054 \mathrm{~g}$ dapat menurunkan trigliserida, sesuai dengan hasil penelitian di Korea yang mendapatkan pemberian propolis $75 \mathrm{mg} / \mathrm{kg}$ dapat menurunkan trigliserida tikus dengan diit tinggi kolesterol $1 \%$ dan sodium cholate $0,25 \%$ (12).

Rerata kolesterol HDL hewan coba pada kelompok I, III, dan IV meningkat pada akhir perlakuan, dengan rerata peningkatan kolesterol $\mathrm{HDL}$ paling tinggi pada kelompok IV (5,5 mg/dl). Rerata peningkatan kolesterol HDL paling rendah terjadi pada kelompok I $(1,8 \mathrm{mg} /$ dl) karena hanya mendapat pakan standar. Sedangkan 
rerata kolesterol HDL hewan coba kelompok II menurun pada akhir perlakuan $(6,5 \mathrm{mg} / \mathrm{dl})$ karena hanya mendapat pakan tinggi kolesterol saja. Rerata kolesterol HDL hewan coba kelompok III meningkat $(3,5 \mathrm{mg} / \mathrm{dl})$ pada akhir perlakuan karena selain mendapat pakan tinggi kolesterol juga mendapat propolis $0,027 \mathrm{~g}$, demikian juga dengan rerata kolesterol HDL kelompok IV meningkat (5,5 mg/ dl) pada akhir perlakuan karena selain mendapat pakan tinggi kolesterol juga mendapat propolis 0,054 g. Hal ini menunjukkan bahwa propolis $0,027 \mathrm{~g}$ dan $0,054 \mathrm{~g}$ dapat meningkatkan kadar kolesterol HDL sesuai hasil penelitian di Korea yang membuktikan bahwa pemberian propolis $75 \mathrm{mg} / \mathrm{kg}$ dapat meningkatkan kolesterol HDL tikus dengan diit tinggi kolesterol $1 \%$ dan sodium cholate $0,25 \%$ (12).

Rerata kolesterol LDL hewan coba meningkat pada akhir perlakuan terjadi pada kelompok I (0,3 mg/dl) dan kelompok II (11,5 mg/dl) sedangkan rerata kolesterol LDL hewan coba menurun pada akhir perlakuan terjadi pada kelompok III (2,1 mg/dl) dan kelompok IV (12,2 mg/dl). Penurunan rerata kolesterol LDL kelompok IV lebih banyak daripada kelompok III karena dosis propolis kelompok IV $(0,54 \mathrm{~g})$ dua kali lebih tinggi daripada dosis propolis kelompok III $(0,27 \mathrm{~g})$. Hal tersebut sesuai dengan hasil penelitian di Texas, Amerika Serikat bahwa diit asam lemak jenuh dapat menekan aktivitas reseptor lipoprotein densitas rendah (kolesterol LDL) (26). Selain itu, hasil penelitian ini sejalan juga dengan penelitian di Korea yang mendapatkan pemberian propolis $75 \mathrm{mg} / \mathrm{kg}$ dapat menurunkan kolesterol LDL tikus dengan diit tinggi kolesterol $1 \%$ dan sodium cholate 0,25\% (12). Hal ini menunjukkan bahwa semakin besar dosis propolis, dapat menurunkan kolesterol LDL semakin besar pula.

Hasil uji analisis dengan One Way Anova dan Kruskal Wallis menunjukkan bahwa terdapat perbedaan bermakna perubahan kolesterol total, perubahan trigliserida, dan perubahan kolesterol HDL namun tidak terdapat perbedaan bermakna perubahan kolesterol LDL. Hal ini menunjukkan bahwa propolis mempunyai efek hipolipid atau dapat memperbaiki profil lipid yaitu dapat menurunkan kolesterol total dan trigliserida serta dapat meningkatkan kolesterol HDL. Hal ini disebabkan propolis mengandung vitamin $\mathrm{C}$, vitamin $\mathrm{E}$, steroid, dan flavonoid sebagai antioksidan yang dapat melindungi sel lemak dari proses oksidasi (peroksidase). Kemampuan hipolipid propolis kemungkinan juga diperankan oleh senyawa steroid dan antioksidan yang terkandung (11).

Kombinasi kandungan vitamin $\mathrm{C}$ dan $\mathrm{E}$ pada propolis sangat efektif, sehingga terjadi efek sinergis antioksidan karena vitamin E akan lebih efektif kerjanya dengan diperkuat vitamin C. Vitamin E dapat melindungi membran lipid dari proses oksidasi. Vitamin E merupakan vitamin larut lemak berhubungan dengan lipoprotein (6). Vitamin $\mathrm{E}$ efektif menghentikan reaksi radikal bebas. Radikal vitamin $\mathrm{E}$ dapat berinteraksi secara langsung dengan radikal peroksi lemak sehingga kehilangan atom hidrogen lain, menghentikan peroksidasi lemak radikal bebas dengan memberikan elektron tunggal untuk membentuk tokoferil kuinon yang stabil (25). Aksi vitamin C dan E melindungi membran teroksidasi sempurna, selain itu kerja vitamin $\mathrm{E}$ diperkuat oleh vitamin C (27).

\section{KESIMPULAN DAN SARAN}

Penggunaan propolis bersamaan dengan pakan tinggi kolesterol dapat menghambat peningkatan konsentrasi profil lipid darah tikus yang diinduksi menjadi hiperlipidemia. Propolis dosis 0,027 g dan 0,054 g dapat memperbaiki profil lipid darah tikus yang diberi pakan tinggi kolesterol, yaitu dapat menurunkan kolesterol total, trigliserida, dan meningkatkan kolesterol HDL, namun belum diketahui pada hari ke berapa mulai terjadi efek hipolipid propolis. Oleh karena itu perlu penelitian lebih lanjut untuk mengetahui efek hipolopid propolis pada penggunaan berapa hari serta penelitian lebih lanjut efek propolis terhadap histopatologi hepar dan jantung.

\section{RUJUKAN}

1. Purwaningsih E, Sugiri. Gizi dan kesehatan jantung. Harapan baru pencegahan dan pengelolaan penyakit jantung iskemik. Semarang: Badan Penerbit Universitas Diponegoro Semarang; 2008.

2. Riset Kesehatan Dasar. Laporan hasil riset kesehatan dasar [serial online] 2007 [cited 2012 Jan 2]. Available from: http://www.docstoc.com/Laporan-Hasil-RisetKesehatan-Dasar (Riskes).

3. Guyton AC, Hall JE. Buku ajar fisiologi kedokteran. Jakarta: Penerbit Buku Kedokteran EGC; 1997.

4. Betteridge DJ. Lipid in current perspective. United Kingdom: Martin Duniltz Ltd; 1996.

5. Anwar TB. Dislipidemia sebagai faktor resiko penyakit jantung koroner. Sumatera Utara: Fakultas Kedokteran Universitas Sumatera Utara; 2008.

6. Rainwater DL, Mahaney MC, Vandeberg JL, Wang $\mathrm{XL}$. Vitamin E dietary supplementation significantly affects multiple risk factors for cardiovascular disease in baboons. Am J Clin Nutr 2007;86:597-603.

7. Ganiswara SG. Farmakologi dan terapi. Jakarta: Gaya Baru; 2003.

8. Limantara, Leenawati, Rahayu, Puji. Studi lapangan kandungan klorofil in vivo beberapa tumbuhan hijau di Salatiga dan sekitarnya. Jakarta: Seminar MIPA; 2005.

9. Jamal S, Suhardi. Penggunaan obat tradisional oleh anggota rumah tangga Jawa dan Bali menurut SKRT 1995. Media Litbangkes 1999;VII(3,4):10-3.

10. Anonim-1. Propolis diamond (bee pollen/royal jelly/ propolis) [serial online] 2009 [cited 2010 Feb 4]. Available from: www.dutaherbal.com. 
11. El-Sayed el-SM, Abo-Salem OM, Aly HA, Mansour AM. Potential antidiabetic and hypolipidemic effects of propolis extract in streptozotocin-induced diabetic rats. Pak J Pharm Sci 2009;22(2):168-74.

12. Myung-Sang K, Zhong-Zhe H, Soo-Yeon $P$, Hyoung-Chun $\mathrm{K}$, Sang-Duk K. Effects of propolis on the accumulation cholesterol induced by high-cholesterol diet in rats [serial online] 2009 [cited 2010 July 15]. Available from: www. apinetla.com.ar/congreso/15.pdf

13. Linawati M, Bagiada M. Pengaruh propolis terhadap sekresi interleukin-12 pada supernatan kultur makrofag dari penderita tuberkulosis paru yang diinfeksi Mycobacterium tuberculosis [serial online] 2009 [cited 2010 June 5]. Available from: ejournal.unud.ac.id.

14. Seven PT, Yilmaz S, Seven I, Cerci IH, A Azman M, Yilmaz M. Effects of propolis on selected blood indicators and antioxidant enzyme activities in broiler unders heat stress. ACTA VET. BRNO 2009;78:75-83.

15. Lotfy M. Biological activity of bee propolis in health and disease. Asian Pac J Cancer Prev 2006;7(1):22-31.

16. Geckil H, Ates B, Durmaz G, Erdogan S, Yilmaz I. Antioxsidant, free radical scavenging and metal chelating characteristics of propolis. Am J Biochem Biotechnol 2005;1(1):27-31.

17. Ramos AFN, Miranda JL. Propolis: a review of its antiinflamatory and healing action. J Venom Anim Toxins Inci Trop Disc 2007;13(4):697-710.

18. Kusumawati D. Bersahabat dengan hewan coba. Yogyakarta: Gadjah Mada University Press; 2004.

19. Momuat LI. Minyak sawit mempercepat regresi aterosklerosis aorta pada kelinci hiperlipidemia ringan tetapi tidak pada hiperlipidemia berat. Prosiding
Seminar Nasional Tanaman Obat dan Obat Tradisional; 2007 Juli 10-11; Surakarta.

20. Elizabeth BEK. Ekstrak daun jati belanda (Guazuma ulmifolia Lakl) penurun kolesterol tanpa mengganggu fungsi hati. Prosiding Seminar Nasional Tanaman Obat dan Obat Tradisional; 2007 Juli 10-11; Surakarta.

21. Dahlan MS. Statistik untuk kedokteran dan kesehatan. Jakarta: Salemba Medika; 2008.

22. (KKI) Kelompok Kerja IImiah Phyto Medica. Pedoman pengujian dan pengembangan fitofarmaka. Jakarta: Yayasan Pengembangan Obat Bahan Alam Phyto Medica; 1993.

23. Chambers CM, Ness GC. Dietary cholesterol regulates hepatic 3-hydroxy-3-methylglutaryl coenzyme a reductase gene expression in rats primarily at the level of translation. Arch Biochem Byophys 1998;354(2):31722.

24. Murray RK. Harper's biochemistry. Alexander HS, editor. Andry H (Alih bahasa). Jakarta: Penerbit Buku Kedokteran; 1999.

25. Marks DB, Marks AD, Smith CM. Biokimia kedokteran dasar, sebuah pendekatan klinis. Brahm U Pendit (Alih bahasa). Jakarta: EGC; 2000.

26. Grundy SM.Multifactorial etiology of hypercholesterolemia: implication of prevention coronary heart disease (review). Artherioscler Thromb 1991;11(6):1619-35.

27. Rukmasari EA, Hadi H, Achadiono DNW. Pengaruh suplementasi vitamin $\mathrm{C}$ dan vitamin $\mathrm{E}$ terhadap profil lipid pada pasien penyakit jantung koroner di Poliklinik Kardiologi RSU dr.Slamet Garut. Sains Kesehatan 2006;19(2). 